Indonesian Journal of Theology 7/1 (July 2019): 88-110

\title{
DEKOLONIALISASI PENDIDIKAN AGAMA KRISTEN DI INDONESIA
}

\section{Mariska Lauterboom}

\begin{abstract}
This paper explores the importance of decolonizing Christian religious education in Indonesia, especially in churches that were established during Dutch colonialism, by engaging in an expressly postcolonial and decolonial approach. After briefly tracing and criticizing the long history of Western colonialism concerning educational practice, this paper presents a variegated rationale connecting the content, relations, and methods within education in the present moment with those of the past-such that education today be seen as reflecting traces of the oppressive and colonizing education of yesteryear. The alternative to this is decolonization, by which a decolonial imagination attends that relational space of teaching-learning in order to transform and liberate Christian religious education in the postcolonial context of Indonesia. In this imagination, there is no body/mind dualism nor sacred/profane binary, and God is present to meet all as Liberator.
\end{abstract}

Keywords: Decolonization, postcolonial, Christian religious education, Indonesia, imagination.

\begin{abstract}
Abstrak
Tulisan ini mengeksplorasi pentingnya dekolonialisasi pendidikan agama Kristen di Indonesia, khususnya di gereja-gereja legasi kolonial Belanda, dengan menggunakan pendekatan poskolonial dan dekolonial. Setelah secara singkat menelusuri dan mengkritisi sejarah panjang kolonialisme Barat dalam kaitan dengan praktik pendidikan, tulisan ini menjabarkan berbagai rasional berkaitan dengan konten, relasi dan metode pendidikan di masa kini yang merefleksikan jejak pendidikan masa lalu yang menindas dan menjajah. Dekolonialisasi melalui imajinasi dekolonial dalam ruang relasi belajar-mengajar hadir sebagai alternatif transformasi dan liberasi pendidikan agama Kristen di konteks poskolonial Indonesia. Dalam imajinasi ini, dualisme tubuh dan pikiran serta sakral dan profan ditiadakan, dan Tuhan hadir berjumpa dengan semua sebagai Sang Pembebas.
\end{abstract}

Kata-kata Kunci: Dekolonialisasi, poskolonial, pendidikan agama Kristen, Indonesia, imaginasi. 


\section{Pendahuluan}

Mengalami secara langsung kerusuhan bernuansa suku dan agama, juga sosial dan politik, di Ambon, Maluku, selama lebih dari 2 tahun, yaitu sejak Januari 1999 sampai dengan Juni 2001, telah memotivasi saya untuk menekuni bidang teologi, secara khusus pendidikan agama Kristen (pendidikan Kristiani) sebagai upaya untuk membangun perdamaian di tanah Maluku, Indonesia. Masih teringat jelas ketika saya harus berlari tanpa alas kaki hanya untuk menyelamatkan diri karena ada pihak tidak dikenal datang menyerang kampung saya. Kerusuhan Maluku yang diawali dari masalah sederhana, bertahan selama kurang lebih empat tahun, menelan ribuan nyawa, menghancurkan banyak sarana-prasarana publik dan menciptakan segregasi di tengah kehidupan masyarakat. Lailatul Fitriyah, dalam tulisannya tentang "Religious Peacebuilding in PostWar Maluku," berpendapat bahwa hilangnya budaya lokal pelagandong dan pandangan kosmologi nunusaku yang mendukung budaya ini adalah salah satu faktor utama pecahnya hubungan masyarakat Kristen dan Muslim Maluku. ${ }^{1}$

Budaya lokal yang dimiliki masyarakat Maluku dan juga masayarakat-masyarakat lainnya di Indonesia terdiri atas beragam bentuk, seperti adat-istiadat, cerita rakyat, lagu daerah, tarian, sampai kepada mitos-mitos tentang terjadinya dunia dan alam semesta serta manusia (kosmologi). Budaya lokal yang sangat kaya ini dapat dikembangkan menjadi landasan, model dan metode dalam pendidikan, termasuk pendidikan agama Kristen. Pendidikan agama Kristen yang dimaksudkan disini adalah yang diselenggarakan oleh pihak gereja, yaitu gereja-gereja yang mewarisi legasi kolonialisme (Belanda).

Selama penjajahan oleh bangsa-bangsa Eropa, secara khusus Belanda, budaya lokal ini dibatasi bahkan dilarang karena dianggap lebih rendah dari budaya Eropa dan bertentangan dengan iman Kristen dan tentunya Alkitab. Alkitab yang dibawa oleh penjajah yang awalnya dikomunikasikan dengan bahasa asing bagi rakyat di daerah-daerah, begitu diagungkan oleh misionaris dan juga oleh orang Kristen Indonesia sampai saat ini.

Pendidikan agama Kristen yang diselenggarakan oleh gereja menggunakan Alkitab sebagai sumber narasi utama dan mengabaikan

${ }^{1}$ Lailatul Fitriyah, "Religious Peacebuilding in Post-War Maluku: Tiwery's Theology of the Mother (Teologi-Ina) and Nunusaku-based Cosmology," Interreligious Relations, No. 10 (2019): 1. Lihat juga John Pieris, Tragedi Maluku: Sebuah Krisis Peradaban (Jakarta: Yayasan Obor Indonesia, 2004), 82, 88, 89, 177. 
narasi-narasi budaya lokal. Pendidikan agama yang berpusat pada Alkitab (Bible-centered) dan narasi bangsa Israel lalu juga menjadi berpusat pada misionaris atau pendeta (Pastor-centered). Tabita Kartika Christiani berpendapat bahwa di gereja telah terbentuk budaya diam karena adanya kesenjangan antara pesan Alkitab yang dibawakan dengan kehidupan nyata jemaat sehari-hari. ${ }^{2}$ Narasi budaya lokal dan narasi pengalaman hidup jemaat setiap hari belum mendapatkan tempat dan peran strategis dalam upaya pendidikan yang diselenggarakan oleh gereja. Dengan ini maka dekolonialisasi pendidikan agama Kristen di konteks Indonesia merupakan suatu kebutuhan.

Artikel ini mengeksplorasi pentingnya dekolonialisasi pendidikan agama Kristen dengan menggunakan pendekatan poskolonial dan dekolonial. Menjawab maksud ini, tulisan ini dibagi atas empat bagian. Bagian pertama tulisan ini akan memaparkan tentang dekolonialisasi, secara khusus di bidang pendidikan, sebagai bagian dari pendekatan atau studi poskolonial dan dekolonial. Pada bagian kedua akan dijelaskan tentang sejarah pendidikan agama Kristen di Indonesia, berfokus pada zaman kolonial Belanda. Lensa poskolonial akan digunakan untuk mengkritisi sejarah penjajahan. Bagian ketiga adalah tentang rasionalitas di balik pentingnya upaya dekolonialisasi pendidikan agama Kristen. Akhirnya, saya akan menjelaskan tentang imajinasi dekolonial, strategi dekolonialisasi dan bagaimana dekolonialisasi menjadi bagian dari upaya berteologi lokal. Dekolonialisasi bukan hanya berkaitan dengan konten, metode, dan model untuk pendidikan agama, tapi juga sekaligus mengarah pada lahirnya teologi berbasis budaya. Harus diakui bahwa apa yang saya deskripsikan ini adalah langkah awal upaya dekolonialisasi di setting gereja, di mana masih dibutuhkan penelitian di tiap-tiap konteks yang tentunya melibatkan baik pendeta dan jemaat sebagai sesama peneliti (co-researchers).

\section{Memahami Dekolonialisai}

Dekolonialisasi dalam bidang pendidikan bukanlah sesuatu yang baru. Dalam Decolonizing Education: Nourishing the Spirit, Marie Battiste berbicara tentang dekolonialisasi pendidikan di konteks

2 Tabita Kartika Christiani, "Biarkan Mereka Bercerita: Pendidikan Kristiani dan Keadilan Gender," dalam Perempuan Indonesia dalam Karya dan Pengabdian, eds., Deetje Rotinsulu Tiwa and Mariska Lauterboom (Jakarta: BPK. Gunung Mulia, 2014), 15. 
Kanada. ${ }^{3}$ Battiste mendeskripsikan tentang apa yang disebut sebagai "asimilasi terpaksa" dalam bidang pendidikan bagi suku aborigin, sebagai sesuatu yang harus ditantang dengan jalan memikirkan kembali tentang keseluruhan sistem pendidikan di Kanada. Ia menentang pola yang berpusat pada Eropa dan mengembangkan strategi dekolonialisasi yang berpihak pada mereka yang tertindas. Di konteks Afrika, Norah Barongo-Muweke juga mengembangkan teori dekolonialisasi pendidikan. ${ }^{4}$ Baginya, dekolonialisasi pendidikan harus mencakup dekolonialisasi kesadaran, kurikulum dan produksi pengetahuan. Dari apa yang dilakukan oleh Battiste di Kanada dan Barongo-Muweke di Afrika, dekolonialisasi dapat dipahami sebagai bukan hanya sekadar upaya dekolonialisasi pemikiran, tapi juga tindakan; dekolonialisasi kesadaran dan sistem, strategi dan praksis, struktur dan kurikulum. Dekolonialisasi perlu dilakukan secara menyeluruh.

Mengaplikasikan pendekatan dekolonial pada metode penelitian, Linda Tuhiwai Smith, salah seorang pionir dalam studi dekolonial, mengkritik penelitian yang berakar pada sistem global kapitalisme dan kekuasaan. ${ }^{5}$ Baginya penelitian berhubungan erat dengan kolonialisme dan imperialisme Eropa. Penelitian dan para peneliti hanya menyediakan sedikit atau bahkan tidak ada kesempatan sama sekali bagi para partisipan dalam penelitian untuk memvalidasi data, temuan, interpretasi, dan klaim yang dibuat oleh peneliti. Dekolonialisasi adalah pemikiran revolusioner tentang peran, produksi, hierarki, dan insititusi ilmu dalam transformasi sosial. ${ }^{6} \mathrm{Hal}$ ini berarti dekolonialisasi dibutuhkan dalam dunia pendidikan di mana ilmu (sebagai knowledge and wisdom) diproduksi dan ditransfer. Apa yang dilakukan oleh Smith merupakan kontribusi penting dalam upaya dekolonialisasi pendidikan dengan menyediakan dasar pijak untuk berpikir dan mengkritisi bukan hanya metode penelitian dan pembelajaran, tapi juga keseluruhan kurikulum pendidikan yang bertujuan untuk transformasi individual dan komunal.

Dalam bidang teologi, usaha dekolonialisasi juga bukan sesuatu yang baru. Fernando Segovia menggunakan istilah dekolonialisasi untuk merujuk pada proses "decentering and liberation" (melepaskan diri

3 Marie Battiste, Decolonizing Education: Nourishing the Learning Spirit (Saskatoon, SK, Canada: Purich Publishing Limited, 2013), 16.

${ }^{4}$ Norah Barongo-Muweke, Decolonizing Education: Towards Reconstructing a Theory of Citizenship Education for Postcolonial Africa (Hannover: Springer, 2016).

5 Linda Tuhiwai Smith, Decolonizing Methodologies: Research and Indigenous Peoples (London, New York, and Dunedin: Zed Books Ltd and University of Otago Press, 2004), 1.

${ }^{6}$ Ibid., xii. 
dari pusat dan pembebasan). ${ }^{7}$ Baginya proses ini adalah keluar atau beranjak dari akar dan perhatian Eropa/Barat. Menggunakan konsep dekolonialisasi, Segovia menantang paradigma-paradigma dominan interpretasi Alkitab dan mengusulkan suatu pedagogi Alkitab. Musa W. Dube, seorang teolog feminis poskolonial dari Afrika, menggunakan dekolonialiasi untuk menghubungkan poskolonial dengan interpretasi feminis terhadap Alkitab. ${ }^{8}$ Dube menggunakan konsep dekolonialisasi untuk menjelaskan tentang strategi literasi yang menolak imperialisme. Dube menolak baik penindasan patriarkal maupun imperialis dalam rangka apa yang ia klaim sebagai "liberating interdependence," interdependensi yang membebaskan. ${ }^{9}$ Pendekatan ini berfokus pada keterkaitan antara beragam narasi dalam konteks global dan spesifik, serta menghargai beragam narasi tersebut. Dalam upaya Dube ini, dekolonialisasi berkaitan dengan resistensi dan strategi melawan imperialisme menuju pembebasan.

Pendekatan Dube inilah yang kemudian dikembangkan oleh salah seorang ahli pendidikan agama Kristen, Boyung Lee, sebagai upaya untuk mentransformasi jemaat melalui upaya pendidikan interkultural. ${ }^{10}$ Lee juga mengklaim tentang vitalnya pedagogi Alkitab yang membebaskan (liberative biblical pedagogy). Bagi saya apa yang dilakukan Lee ini adalah wujud dari upaya dekolonialisasi pendidikan agama Kristen. Selain Lee, pendekatan yang ditawarkan oleh Christiani dalam melawan budaya diam dengan menyediakan tempat aman bagi warga jemaat (khususnya perempuan) untuk bercerita dan berbagi pengalaman hidup melalui pendekatan reflektif, juga adalah upaya dekolonialisasi pendidikan agama Kristen di konteks Indonesia. Justitia Hattu dengan gagasan pembelajaran transformatif yang menjawab tantangan hidup berbangsa dan bernegara, juga merupakan bagian dari upaya dekolonialisasi pendidikan Kristiani. ${ }^{11}$ Sejalan dengan Christiani dan Hattu, Nancy Souisa juga turut mengupayakan dekolonialisasi. ${ }^{12}$

7 Fernando Segovia, Decolonizing Biblical Studies: A View from Margin (Maryknoll: Orbis Books, 2000), xi, 7.

8 Musa W. Dube, Postcolonial Feminist Interpretation of the Bible (St. Louis, Missouri: Chalice Press, 2000), 185-186.

9 Ibid., 111, 185-186.

10 Boyung Lee, Transforming Congregations through Community: Faith Formation from the Seminary to the Church (Louisville, Kentucky: Westminster John Knox Press, 2013. Lihat juga Boyung Lee, "Toward Liberating Interdependence: Exploring an Intercultural Pedagogy," Religious Education, Vol. 105, No. 3 (2010): 284.

11 Justitia Vox Dei Hattu, Mewarga Dengan Hati: Pembelajaran Transfromatif sebagai Respon Pedagogis Kristiani terhadap Tantangan Pendidikan Kewarganegaraan dalam Konteks Indonesia Masa Kini (Jakarta: BPK. Gunung Mulia dan ST'T Jakarta, 2018).

12 Nancy Souisa, "Makan Patita: Nilai dan Maknanya dalam Membangun Pendidikan Kristiani yang Kontekstual," disertasi (Universitas Kristen Satya Wacana, 2017). 
Dalam disertasi doktoralnya, ia mengangkat nilai-nilai dalam budaya makan patita di Maluku untuk dijadikan sebagai landasan filosofis pendidikan agama Kristen.

Dekolonialisasi menunjuk pada proses beranjak dari kolonialisme ke poskolonialisme, dari penjajahan kepada liberasi atau pembebasan, decentering Barat (melepaskan diri dari keterpusatan pada dunia Barat), menantang normativitas yang berlaku di masyarakat, dan dari pendekatan multikultural ke interkultural. Dekolonialisasi berarti memberi tempat bagi dan mengakui peran strategis dari budaya lokal, seperti makan patita di Maluku. Dekolonialisasi adalah bentuk dukungan bagi mereka yang tertindas (seperti misalnya perempuan Indonesia), sekaligus upaya untuk mendorong kesadaran dan refleksi kritis yang berujung pada aksi atau praksis nyata. Sebagai sebuah pendekatan, dekolonialisasi adalah bagian dari studi poskolonial dan dekolonial, yang sama-sama berhubungan dengan isu kolonialisme dan imperialisme. ${ }^{13}$ Poskolonial dan dekolonial, sebagai konsep dan pendekatan, punya potensi untuk mendisrupsi, untuk bertanya dan merekonstruksi standar produksi ilmu pengetahuan dan formasi identitas, termasuk dalam area pendidikan seperti pendidikan yang diselenggarakan oleh gereja. Poskolonial dan dekolonial berhubungan dengan isu identitas dan dominasi, sekaligus juga tentang perjuangan untuk bagaimana membawa perubahan yang adil atas ketidakadilan yang terus terjadi setelah penjajahan. ${ }^{14}$ Perjumpaan antara pendidik dan nara didik dalam upaya dekolonialisasi dipahami dalam kaitan dengan konsep hibriditas dan third-space (ruang antara, ruang ketiga). ${ }^{15}$ Hibriditas mengacu pada kemajemukan dan relasi yang interdependen serta meniadakan dualisme. Batasan di antara budaya atau di antara berbagai identitas adalah ruang kreatif di mana identitas seseorang ditantang dan dinegosiasi. Hibriditas merefleksikan dinamika budaya dan identitas, bahwa budaya dan identitas terus berubah dan dipengaruhi oleh konteks perjumpaan antara penjajah dengan yang dijajah.

\section{Sejarah Pendidikan Agama Kristen di Indonesia}

13 Studi-studi serta teori poskolonial dan dekolonial berkembang dari konteks sosio-historis yang berbeda. Lihat Gurminder K. Bhambra, "Postcolonial and Decolonial Dialogues," Postcolonial Studies, Vol. 17, No. 2 (2014): 115-121, https://www.tandfonline.com/doi/pdf/10.1080/13688790.2014.966414.

14 Jennifer Lavia and Sechaba Mahlomahalo, eds., Culture, Education and Community: Expressions of the Postcolonial Imagination (New York: Palgrave Macmillan, 2012), ix.

15 Homi K. Bhabha, The Location of Culture (London and New York: Routledge, 1994). 
Sejarah pendidikan agama Kristen di Indonesia berkaitan dengan sejarah kolonialisme bangsa-bangsa Eropa. Sejarah ini penting untuk ditelusuri dan dikritisi dengan pendekatan poskolonial karena legasi dari apa yang terjadi puluhan bahkan ratusan tahun lalu masih nampak dan berpengaruh dalam desain dan praktik pendidikan agama Kristen di gereja masa kini.

Penjajahan yang dialami oleh rakyat di berbagai pulau di negara yang kemudian disebut Indonesia, terjadi selama ratusan tahun dan dalam bentuk yang beragam, baik secara fisik maupun non-fisik. Tidak banyak referensi yang secara khusus berbicara tentang sejarah pendidikan agama Kristen di Indonesia. Salah satu yang menulis topik tersebut adalah Robert Boehlke. Baginya, sejarah pendidikan agama Kristen dimulai sejak zaman penjajahan bangsa Portugis. ${ }^{16}$ Portugis tiba pertama kali di Ternate pada tahun 1538 dan mendirikan sekolah dalam rangka pemberitaan injil (gospe). Pendidikan agama Kristen (Katolik) pertama kali pada zaman Portugis dilakukan dalam bentuk yang sederhana yaitu pengajaran katekismus dari seorang imam yang telah diterjemahkan sebelumnya oleh Fransiscus Xaverius dari Ordo Yesuit. Metode yang digunakan adalah memorisasi atau hafalan. Para murid diwajibkan untuk menghafal doa Bapa Kami, Sepuluh Hukum, dan Pengakuan Iman Rasuli, di samping belajar bahasa Portugis. Metode memorisasi ini terus digunakan oleh Belanda yang menyebarkan agama Kristen Protestan. Pergerakan Reformasi di abad ke-16 yang turut mempengaruhi pekerjaan misi Protestantisme di Indonesia memang menekankan intelektualitas dan iman yang rasional. Para Reformator seperti Martin Luther dan Yohanes Calvin berfokus pada pendidikan sebagai tanggung jawab gereja dan sebagai tempat pertempuran ideologi, sehingga tidak mengherankan jika upaya pembentukan kognitif warga jemaat, termasuk melalui metode memorisasi, menjadi pilar utama pendidikan gereja. ${ }^{17}$

Perjumpaan antara penjajah dengan yang dijajah menghasilkan hubungan yang unik dan dinamis yang berpengaruh kepada kedua belah pihak, termasuk dalam pendidikan yang diselenggarakan gereja. Ada banyak badan zending/mission yang melayani di Indonesia selama 350 tahun masa penjajahan di Indonesia. Saya secara khusus melihat

${ }^{16}$ Robert R. Boehlke, Sejarah Perkembangan Pikiran dan Praktik Pendidikan Agama Kristen: Dari Yohanes Amos Comenius sampai Perkembangan PAK di Indonesia (Jakarta: BPK. Gunung Mulia, 2009), 767.

${ }^{17}$ Justitia Vox Dei Hattu, "Protestantisme dan Pendidikan Kristiani," dalam Menuju Gereja Orang Basudara: Refleksi 500 tahun Protestantisme dari Maluku, eds., Rudolf Rahabeat \& Johan Saimima (Salatiga: Satya Wacana University Press dan Sinode GPM, 2017), 282. 
pendidikan agama Kristen dalam kaitan dengan misi yang dilakukan oleh bangsa Belanda (di Maluku) karena dalam masa penjajahan ratusan tahun, sistem pendidikan di Indonesia dirancang oleh Belanda. Badan misi lainnya, seperti milik Jerman yaitu RMG (Rheinische Missions Gesellschaft), menghasilkan perjumpaan yang berbeda dengan komunitas yang dilayani, yaitu seperti di Sumatra Utara. ${ }^{18}$

Pada zaman Belanda, yang dimulai dengan kehadiran badan dagang Belanda dengan nama VOC (Vereenigde Oost Indische Compagnie), perhatian terhadap perkembangan Injil dan penyebaran agama Kristen bukan menjadi prioritas. Kehadirannya di Maluku memiliki tujuan utama perdagangan dan mengeruk keuntungan yang sebesar-besarnya. Pendidikan, termasuk pendidikan agama, diselenggarakan atas dasar kepentingan VOC. ${ }^{19}$ Perintah umum kepada gereja tahun 1643 terdiri dari lima hal pokok. Pertama, menanamkan rasa takut akan Tuhan bagi anak-anak, mengajarkan inti sari iman Kristen, cara berdoa, menyanyi dan bagi orang tua untuk mengantar anak-anak ke tempat ibadah. Kedua, anak-anak diajarkan untuk taat kepada orang tua dan tokohtokoh berkuasa, termasuk guru. Ketiga, anak-anak diajarkan membaca, menulis dan berhitung. Keempat, guru wajib membina anak-anak dalam hal budi pekerti dan sopan santun. Kelima, penggunaan bahasa Belanda di sekolah, bukan bahasa daerah atau bahasa lokal.

Menurut Boehlke, dengan mendidik anak-anak pribumi dalam bahasa Belanda, maka otoritas atas orang tua anak-anak tersebut dapat diperkuat. ${ }^{20}$ Hal ini menunjukkan bahwa penjajahan oleh Belanda terjadi dalam berbagai bentuk, termasuk penggunaan bahasa penjajah, baik Portugis maupun Belanda, dan bukan bahasa lokal atau bahasa daerah. Bahasa daerah akhirnya menghilang karena tidak digunakan lagi. Bagi Boehlke, pendidikan yang berlangsung menggunakan bahasa asing ini akan sulit dalam pencapaian tujuan. Bahasa bukan hanya sekadar simbol tanpa makna, tapi bahasa berkaitan erat dengan budaya.

Menggunakan bahasa asing sebagai bahasa pengantar dalam pendidikan dan dalam kehidupan beragama tentunya akan mempersulit pemahaman konsep yang diajarkan, baik di sekolah maupun di gereja. ${ }^{21} \mathrm{Hal}$ ini menjadikan pendidikan agama pada zaman

${ }^{18}$ Lihat Jan S. Aritonang, Mission Schools in Batakland (Indonesia): 1861-1940, trans., Robert R. Boehlke (Leiden: E.J. Brill, 1994), 9.

19 Th. van den End and Jan S. Aritonang, "1800-2005: A National Overview," in A History of Christianity in Indonesia, eds., Jan Sihar Aritonang and Karel Steenbrink (Leiden: Brill, 2008), 138, 148, 149. Kristen, 767.

20 Boehlke, Sejarah Perkembangan Pikiran dan Praktik Pendidikan Agama

21 Tulisan ini pada awalnya saya tulis dalam bahasa asing, yaitu bahasa Inggris, karena privilese yang saya miliki saat ini, yaitu menempuh pendidikan doktoral di Amerika dengan kemudahan akses berbahasa Inggris. Tapi kemudian saya 
itu sulit mencapai tujuan yang sesungguhnya. Memahami proses belajar-mengajar sebagai proses penciptaan makna bersama, maka metode memorisasi dan penggunaan bahasa asing menjadi faktor penghambat dan penghalang proses tersebut. Terlebih lagi dengan fokus utama pada perdagangan, wakil VOC tidak sepenuhnya merencanakan hal-hal yang berkaitan dengan pendidikan dan pedagogi. Kebijakan pendidikan Kristen juga tidak ditentukan oleh gereja tapi oleh VOC; gereja dibangun dan pendidikan diselenggarakan untuk tujuan keuntungan mereka.

Dengan berakhirnya pendudukan VOC di Indonesia, pada akhir abad ke-18 pemerintah Belanda mengambil alih semua urusan termasuk pendidikan. Kehidupan rakyat diatur oleh Belanda dan mereka terpaksa menerima apa saja yang diputuskan oleh penguasa kolonial. ${ }^{22}$ Gereja dan badan misi diizinkan mendirikan sekolah swasta di mana agama Kristen diajarkan kepada anak-anak. Sekolah minggu didirikan dengan membawa ciri khas Eropa. Sejak tahun 1830, usaha pendidikan diambil alih oleh badan misi Protestan yang dikenal sebagai Nederlandsch Zendelinggenoottschap. Secara kronologis, pendidikan di zaman Belanda pertama kali disponsori oleh pemerintah Belanda, kemudian diikuti oleh lembaga-lembaga zending. Menurut Jan Aritonang, lembaga-lembaga zending ini mengikuti pola pendidikan yang telah lebih dulu dikembangkan oleh pemerintah Belanda. ${ }^{23} \mathrm{Hal}$ ini menunjukkan bahwa kebutuhan konteks masyarakat pada zaman itu, termasuk budaya lokal dan adat, tidak diperhitungkan sebagai penentu kebijakan pendidikan yang dikembangkan oleh gereja atau badan misi. Budaya lokal dianggap lebih rendah dari budaya Barat, bahkan dicap kafir.

Arah pendidikan agama Kristen setelah abad ke-18, menurut Boehlke, dipengaruhi oleh konferensi studi pendidikan agama di Sukabumi tahun 1955 dan ceramah Elmer G. Homrighausen atas teori pendidikan, serta usaha meredakan ketegangan kreatif antara

menerjemahkannya ke dalam bahasa Indonesia sebagai bentuk pernyataan dekolonialisasi pendidikan Indonesia. Ternyata tidak mudah upaya penerjemahan itu, karena bahasa berkaitan dengan budaya (cara pikir dan mengekpresikan sesuatu). Dapat dibayangkan pendidikan di zaman kolonial yang awalnya dalam bahasa penjajah, baru kemudian bahasa Melayu dan bahasa daerah setempat. Betapa sulitnya penciptaan makna bersama (meaning making) diwujudkan sebagai tujuan pendidikan yang membebaskan.

22 Sinode Gereja Protestan Maluku, "Gereja Protestan Maluku (18001864)," diakses 20 Januari 2020, https://www.sinodegpm.org/halaman/detail/gereja-protestan-di-maluku. Lihat juga Th. van den End, Ragi Carita: Sejarah Gereja di Indonesia 1, 1500-1860 (Jakarta: BPK. Gunung Mulia, 1988).

23 Aritonang, Mission Schools in Batakland (Indonesia), 9. 
pendidikan agama Kristen dan pembinaan warga jemaat, dan refleksi terhadap teori dan praktik pendidikan di masa depan. ${ }^{24}$ Homrighausen yang adalah guru besar pendidikan agama Kristen di Princeton Theological Seminary di Princeton, New Jersey, Amerika Serikat, menolak teologi ortodoks yang kaku maupun liberal. Ia mengikuti pendekatan teologi yang dipelopori Karl Barth. Sejak tahun 1939, Homrighausen menjadi pengkritik terhadap gerakan dan pendekatan dalam pendidikan agama. Baginya pendidikan agama perlu berkaitan dengan pengalaman hidup. Menurt Boelhke, pandangan teologis dan pedagogis Homrighausen sangat sesuai dengan kehidupan gerejagereja di Indonesia. ${ }^{25}$

Apa yang dijabarkan oleh Boehlke tentang sejarah pendidikan agama Kristen di Indonesia berfokus pada tokoh-tokoh asing dan perannya dalam upaya pendidikan di Indonesia. Boehlke mengabaikan peran tokoh-tokoh lokal, seperti misalnya para guru injil dan tenaga misionaris lokal dan pembantu misionaris Portugis dan Belanda yang turut mengupayakan pendidikan rakyat. Hal ini juga menggambarkan betapa pengaruh dunia Barat begitu besar dalam semua aspek kehidupan di Indonesia, termasuk dalam pelaksanaan pendidikan agama Kristen. Di Maluku, misalnya, terdapat guru-guru injil seperti guru Lokolo di Amahai yang memimpin warga jemaat dengan setia, guru Risakotta yang melayani di pulau Saparua, dan sebagainya. Sebagai guru injil, mereka tidak diperkenankan melayani sakramen karena tidak ditabiskan sebagai pendeta oleh pihak Belanda. Apa yang dilakukan oleh guru-guru injil ini harusnya menjadi bagian penting dari catatan sejarah pendidikan agama Kristen di Indonesia. Sayangnya, tidak ada referensi yang cukup menyangkut pekerjaan pelayanan mereka.

Berdasarkan uraian singkat tentang sejarah panjang penjajahan Indonesia dalam kaitan dengan bidang pendidikan, maka ada dua hal penting. Pertama, menyangkut pendidikan dengan tujuan keagamaan, peran para misionaris sangat signifikan. Mereka melayani sebagai guru di sekolah dan guru di gereja. Mereka menolong rakyat untuk membaca, menulis, dan belajar tentang kekristenan. Ada banyak gedung gereja dan sekolah yang dinamakan sesuai dengan nama para misionaris, seperti Xaverius dan Joseph Kam. Relasi yang unik terbangun antara rakyat dan penjajah yang bisa dilihat melalui lensa poskolonial, secara khusus melalui konsep hibriditas. Khusus untuk konteks Maluku, tidaklah mengherankan kalau sebagian besar rakyat Maluku sampai saat ini begitu mengidentikkan diri mereka dengan Belanda, bukan hanya karena bagitu banyak orang Maluku yang Kristen, 770

24 Boehlke, Sejarah Perkembangan Pikiran dan Praktik Pendidikan Agama 25 Ibid., 773. 
berpindah ke Belanda (terpaksa ataupun tidak) pada zaman penjajahan dan menetap di sana sampai saat ini, tapi juga karena perjumpaan yang unik yang melibatkan kekristenan antara orang Maluku dan orang Belanda. Sampai saat ini Gereja Protestan Maluku masih menjalin kerja sama dengan badan zending/misi di Belanda. Relasi antara dua subjek poskolonial ini, yaitu misionaris dan orang Kristen Indonesia, juga koneksi antara kedua konteks menghasilkan hibriditas. Setelah penjajahan, sulit untuk menarik garis tegas antara budaya dan identitas Indonesia dan Belanda.

Kedua, relasi yang unik dengan para misionaris ini, tidak lalu memungkiri adanya jejak imperalisme budaya dan pedagogi yang membelenggu pada pendidikan agama Kristen yang diselenggarakan oleh gereja, baik secara sadar ataupun tidak. Metode memorisasi, metode monolog dan bukan dialog, otoritas tinggi yang dipegang oleh para misionaris, proses pemberian atau penerusan makna dan bukan penciptaan makna bersama, penggunaan bahasa asing yang lebih dominan, superioritas budaya kolonial, minimalisasi bahkan desakralisasi budaya lokal (adat), semuanya berkontribusi terhadap terjadinya pendidikan agama Kristen yang membelenggu, menindas, dan menjajah (a colonized Christian religious education) yang jejaknya ada sampai saat ini dalam desain dan praktik pendidikan agama Kristen di Indonesia. Guru atau pendeta mengadopsi gaya para misionaris dalam melaksanakan pendidikan, yaitu dalam hal penggunaan Alkitab, relasi dengan nara didik/jemaat, dan di dalam metode serta konten pendidikan itu sendiri. Disinilah pentingnya proses dekolonialisasi supaya pendidikan itu membebaskan, mentransformasi, dan menjadi ruang penciptaan makna bersama yang menjawab kebutuhan hidup baik individual maupun komunal di konteks Indonesia.

\section{Dekolonialisasi Pendidikan Agama Kristen}

Mengapa diperlukan dekolonialisasi pendidikan agama Kristen? Apa tantangan dan peluang upaya ini di konteks poskolonial Indonesia? Poskolonial disini bukan dipahami sebagai rentang waktu setelah kolonialisme berlangsung di mana sudah tidak ada lagi penjajahan, melainkan penggunaan istilah poskolonial justru menggarisbawahi keberlanjutan antara era penjajahan dan zaman setelahnya. Tidak bisa dipungkiri bahwa kolonialisme dan imperialisme telah membentuk kekristenan sejak awal dan legasi dari masa lalu itu masih terus eksis dan berpengaruh dalam konteks kini. Hattu mengklaim bahwa pekerjaan misi oleh Belanda di abad ke-17 dan ke- 
18 memengaruhi kehidupan bergereja warisan Belanda di Indonesia. ${ }^{26}$ Kita masih hidup dalam konsekuensi sejarah penjajahan selama ratusan tahun dan berjumpa dengan berbagai bentuk kolonialisme kontemporer. Kolonialisme ini menghasilkan relasi kuasa yang tidak seimbang, superioritas budaya, dan formasi identitas yang berpusat pada penjajah.

Menurut Ahn Jae Woong, untuk sekian waktu lamanya pendidikan agama Kristen di konteks Asia mengikuti orientasi teologi dari pergerakan misionari zaman kolonialisme dan begitu bergantung pada materi-materi dari Barat. ${ }^{27}$ Dengan ini maka pendidikan oleh gereja-gereja di Asia perlu untuk menjawab tantangan konteks sehingga kekristenan sebagai minoritas, termasuk di Indonesia, bisa bertahan dan menjadi agama lokal, bukan sekadar sebuah produk kolonial. Dengan pemahaman ini seharusnya sudah menjadi landasan pentingnya upaya dekolonialisasi pendidikan agama Kristen di konteks Indonesia. Dengan secara khusus menilik sejarah pendidikan yang dilakukan di zaman kolonial Belanda, maka jelas terlihat bahwa legasi penjajahan terbawa dalam perancangan dan pelaksanaan pendidikan agama Kristen. Upaya dekolonialisasi harus diawali dengan kesadaran akan hal ini dan kemudian mengidentifikasi beragam bentuk kolonialisme kontemporer lainnya dalam praktik pendidikan oleh gereja.

Praktik pendidikan masa kini yang saya kategorikan sebagai bentuk pendidikan yang membelenggu dan menindas (a colonized Christian religious education) diidentifikasikan pada tiga hal utama, yaitu penggunaan Alkitab sebagai sumber dan konten pendidikan agama Kristen, relasi pendeta dan jemaat atau guru dan murid, dan metode belajar-mengajar yang digunakan.

Alkitab yang merupakan sumber utama pendidikan agama Kristen, sejak dibawa oleh penjajah, adalah sesuatu yang sangat penting bagi orang Kristen Indonesia. Penggunaan Alkitab (khususnya di Indonesia bagian Timur di gereja-gereja legasi Belanda) bisa dikategorikan unik karena Alkitab dilihat selain sebagai Firman Tuhan, juga sebagai sebuah objek sakral yang punya kuasa atau kesaktian ( $a$ sacred venerated object). ${ }^{28}$ Alkitab akan selalu dibawa ketika orang bepergian jauh dari rumah dan akan diletakkan tepat di atas kepala bayi

26 Hattu, "Protestantisme dan Pendidikan Kristiani," 283.

27 Ahn Jae Wong, preface to Religious Education in Context of Plurality and Pluralism by Hope S. Antone (Quezon City: New Day Publishers, 2003), vi. Lihat juga Hope S. Antone, "The Shape of Christian Religious Education in Asia," Religious Education Vol. 99, No. 1 (2004): 79-85.

${ }^{28}$ Charles E. Farhadian, Christianity, Islam, and Nationalism in Indonesia (New York and London: Routledge, 2005), 115-116. 
yang baru lahir sebagai wujud permohonan akan perlindungan dari Yang Kuasa dan keyakinan akan kesaktian Alkitab itu sendiri. Narasi kesaktian Alkitab dibangun, seperti ketika terjadi kerusuhan di Ambon oleh karena Alkitab diletakkan di saku jubah, peluru tidak menembus tubuh sang Pendeta. Semua ini adalah bagian dari narasi-narasi lokal tentang pentingnya Alkitab sebagai benda suci dan sakti dalam kehidupan berjemaat yang perlu diakui oleh gereja dan bukan dicap sebagai sesuatu yang mistis yang bertentangan dengan kekristenan.

Terkait membaca dan menafsir Alkitab, Ira Mangillilo mengatakan bahwa orang Indonesia (perempuan) masih menggunakan Alkitab untuk mencari jawaban dan rasa aman di dalam pergumulan mereka. ${ }^{29}$ Alkitab dengan ini merupakan sesuatu yang penting dan berharga bagi komunitas Kristen Indonesia. Persoalannya adalah bagaimana dengan pengajaran Alkitab itu sendiri yang ditawarkan oleh gereja. Apakah dalam aktivitas pendalaman Alkitab (PA) ada tempat yang tercipta atau diciptakan supaya semua yang hendak berbicara dapat didengarkan?

Menurut Christiani, orang Kristen, secara khusus kaum perempuan, tidak berbagi pergumulan kehidupan nyata mereka setiap hari karena tidak ada tempat yang aman dalam praktik pendidikan agama Kristen itu sendiri. ${ }^{30}$ Tidak ada ruang untuk meratap kekerasan dalam rumah tangga yang dialami, baik fisik maupun verbal. Terlebih lagi orang Indonesia tidak terlatih untuk bebas mengekspresikan perasaan dan pengalaman mereka. Dari perspektif pedagogis, Christiani mengklaim bahwa kehidupan setiap hari perempuan Indonesia bertolak belakang dengan pesan ideal pengajaran Kristen yang diterima melalui khotbah, PA dan sekolah minggu. Pengalaman setiap hari diabaikan dalam praktik pendidikan Kristiani. Orang lebih pasif dan tidak mempertanyakan otoritas guru atau pendeta. Mereka menerima apa saja yang diajarkan. Model pendidikan adalah one-way direction, a top-down model, yang menekankan aspek kognitif. Model ini adalah model instruksional yang dimulai dari Alkitab dan berakhir pada relevansi dalam kehidupan setiap hari. Pendidikan menjadi berpusat pada Alkitab. Membatasi konten pendidikan hanya pada Alkitab mencegah nara didik atau warga jemaat untuk mencapai kepenuhan pemahaman yang dibutuhkan untuk menjadi murid yang beriman kepada Tuhan. ${ }^{31}$ Ada banyak konten pendidikan selain Alkitab yang

${ }^{29}$ Ira D. Mangililo, "When Rahab and Indonesian Christian Women Meet in the Third Space," in Journal of Feminist Studies in Religion Vol. 31, No. 1 (2015): 64.

${ }^{30}$ Christiani, "Biarkan Mereka Bercerita," 15.

31 Karen B. Tye, Basics of Christian Education (St. Louis, Missouri: Chalice Press, 2000), 50. 
harus digunakan dalam pendidikan agama Kristen, yaitu meliputi pengalaman setiap hari serta budaya di sekitar termasuk adat.

Pendidikan agama Kristen yang hanya berpusat pada Alkitab menurut Karen B. Tye disebabkan oleh pemahaman dunia Barat tentang ilmu (knowledge) sebagai "proportional knowledge."32 Baginya hal ini merupakan refleksi dari pemahaman yang terbatas tentang ilmu. Gereja menekankan tentang "memahami tentang" (the knowing about) dan "memahami bahwa" (the knowing that) sehingga tujuan dan metode pengajaran adalah bagaimana nara didik mampu menghafal ayat-ayat Alkitab secara jitu dari kata pertama sampai terakhir. Metode memorisasi ini banyak digunakan sejak sekolah minggu. Ini salah satu hal utama dari kegiatan sekolah minggu berpuluh tahun lalu yang masih saya ingat sampai sekarang, yaitu tentang menghafal ayat Alkitab. Ternyata pendekatan ini bisa dirunut jejaknya hingga zaman kolonialisme, di mana para misionaris meminta penduduk lokal untuk menghafal dan mengucapkan ayat-ayat Alkitab. Metode ini yang dikembangkan dalam pengajaran, termasuk dalam ujian katekisasi yang diajarkan gereja. Sejalan dengan ini, Hattu mengungkapkan bahwa pendidikan Kristiani di Indonesia terlalu menekankan dimensi kognitif yang mengakibatkan terjadinya indoktrinasi. ${ }^{33}$ Terkait hal ini, Hattu menyuarakan tentang pendidikan di Indonesia yang perlu untuk beranjak dari yang indoktrinatif ke dialogis. ${ }^{34}$

Pendidikan agama Kristen yang berpusat pada Alkitab dan doktrin ini lalu juga menjadi berpusat pada pendeta (pastor-centered) yang dianggap menguasai keseluruhan Alkitab. Pendekatan seperti ini turut menyumbangkan pendidikan tanpa penciptaan makna bersama antara pendeta dan warga jemaat, juga relasi yang setara. Sistem pendidikan model bank yang dikritik oleh Paulo Freire, ternyata masih mewarnai pendekatan pendidikan gereja. ${ }^{35}$ Minimnya bahkan tidak adanya pengalaman pribadi para nara didik sebagai sumber strategis belajar, seperti yang diungkapkan oleh Christiani, menghasilkan budaya diam (a culture of silence). Fokus pendidikan adalah tentang guru atau pendeta dengan posisi signifikan sebagai wakil Tuhan. Sebagian orang percaya bahwa sebagai warga jemaat mereka tidak dapat berbicara negatif tentang pendeta karena sesuatu yang buruk dapat terjadi pada diri mereka. Hal ini membuat pendeta memegang otoritas superior yang dapat ditelusuri kembali ke kolonialisme. Menurut Frank Cooley, pendeta atau misionaris (yang selalu laki-laki) ditunjuk oleh sinode

\footnotetext{
32 Ibid., 56.

${ }^{33}$ Hattu, Mewarga Dengan Hati, 4.

34 Hattu, "Protestantisme dan Pendidikan Kristiani," 280-297.

35 Paulo Freire, The Pedagogy of the Oppressed (New York: Continuum, 2011).
} 
untuk melayani jemaat desa. ${ }^{36}$ Ia tidak terlibat dalam hubungan kekerabatan, adat, dan tanah dengan penduduk desa yang dilayani. Bersama dengan kepala desa, pendeta/misionaris menikmati posisi tertinggi dalam masyarakat desa, dengan mendapat rasa hormat yang paling tinggi, dan bahkan rasa takut, karena dia adalah orang yang merupakan perwakilan Tuhan.

Pendidik berasumsi bahwa mereka memiliki pengetahuan tertinggi yang kemudian diberikan kepada warga jemaat. Dalam sistem pendidikan model bank ini, metode yang umum adalah narasi di mana guru adalah narator yang mengarahkan siswa untuk menghafal secara otomatis konten yang diriwayatkan. Tidak ada pemikiran kreatif yang dikembangkan oleh siswa; mereka hanya duduk, mendengarkan, dan mencatat. Pendidikan hanyalah tindakan depositori, di mana guru adalah depositor dan siswa adalah penerima pasif. Hubungan yang terjalin adalah monolog, bukan dialog, di mana pembelajaran berjalan dalam satu arah, hanya dari pendeta ke jemaat. Hal ini mengarah pada kurangnya kreativitas dan transformasi jemaat serta tidak ada ruang yang cukup bagi pengalaman setiap hari sebagai sumber belajar tentang Tuhan.

Menghubungkan pengalaman dengan pendidikan adalah prinsip dasar pendidikan, di mana pendidikan tidak boleh mengasingkan siswa dari kenyataan pengalaman sehari-hari mereka. Mereka harus "tahu siapa mereka dan bagaimana mereka berhubungan dengan dunia." 37 Akibatnya, model tradisional pendidikan agama di mana mengajar adalah transfer pengetahuan hanya dari pendeta atau guru ke warga jemaat (top-down), di mana peserta didik tidak memiliki suara dalam proses belajar dan harus berkompromi dengan segala sesuatu, bukanlah pilihan lagi.

Dekolonialisasi juga diperlukan di Indonesia karena pendidikan agama Kristen gagal membahas kekayaan budaya lokal Indonesia dalam kurikulumnya. Tanggung jawab untuk melestarikan adat atau budaya lokal sering dianggap hanya urusan pemerintah. Menengok ke masa penjajahan Belanda, adat dan Kristen berada dalam ketegangan yang menghasilkan dualisme mengenai kepercayaan agama dan cara hidup tradisional. Imperialisme politik dan budaya tidak hanya disebabkan oleh perusahaan perdagangan Belanda tetapi juga oleh pekerjaan misionaris, seperti yang dikemukakan oleh Cooley. ${ }^{38}$ Pada

36 Frank L. Cooley, "Altar and Throne in Central Moluccan Societies," Indonesia, Vol. 2 (1966): 135-156. Lihat juga Frank Cooley, Indonesia: Church and Society (New York: Friendship Press, 1968).

37 Parker Palmer, To Know as We are Known: Education as a Spiritual Journey (New York: Harper Collins, 1993), 16.

38 Cooley, Indonesia, 33. 
zaman VOC, gereja dan negara menjadi satu di mana peran budaya Eropa dan Kristen terlalu dominan, yang mengakibatkan tidak ada tempat bagi budaya lokal. ${ }^{39}$ Sejalan dengan ini, seringkali gereja diam terhadap penindasan yang terjadi di masyarakat, karena dunia bagi gereja adalah realitas terpisah. Ketika ada kebangkitan adat yang digaungkan oleh begitu banyak masyarakat adat, gereja tidak memberikan respons yang serius. Itu sebabnya saya setuju dengan Kwok Pui-Lan bahwa ketimbang menjadi bagian dari rakyat, orangorang Kristen Asia (termasuk Indonesia) malah memisahkan diri dari komunitas dunia. ${ }^{40}$

Nindyo Sasongko menunjukkan kurangnya partisipasi gereja dalam kehidupan publik dengan menganalisis peristiwa pembunuhan massal yang terjadi di Indonesia tahun 1965-1966. Baginya, gereja terjebak dalam "an epistemic ignorance" (suatu pengingkaran atau pengabaian atau ketidaksadaran epistemik). ${ }^{41}$ Pengabaian ini bukan hanya epistemik tapi juga politis, dan gereja perlu berbuat sesuatu. Untuk mengkonfrontasi ignorance ini, Sasongko berpendapat bahwa gereja sebagai komunitas orang beriman harus menemukan jati diri atau identitasnya sebagai komunitas memori dan ratapan (a community of memory and lament). Sejalan dengan ini, bagi Mery Kolimon, gereja perlu mengingat masa lalu ketika terjadi pembunuhan massal dan penghancuran tradisi atau budaya (indigenous traditions) sebagai bagian dari proses penyembuhan. ${ }^{42}$ Kolimon mengklaim bahwa ada kekerasan dan penindasan melawan budaya lokal yang dilakukan oleh agama dan pemerintah. Dalam menjawab kebutuhan untuk meratap dan berbagi kisah hidup, untuk mengekspresikan rasa takut dan pengharapan, juga untuk memberi tempat bagi budaya lokal, upaya dekolonialisasi menjadi penting di Indonesia.

Selain berbagai alasan yang sudah dikemukakan, dekolonialisasi juga dibutuhkan sebagai jawaban atas tantangan polarisasi pendidikan agama Kristen. Polarisasi merujuk pada pengkotak-kotakan upaya pendidikan agama Kristen yang dilakukan oleh keluarga, gereja, sekolah, dan masyarakat. Polarisasi juga terjadi pada kegiatan di dalam dan di luar kelas yang justru mestinya berkesinambungan. Sistem

\footnotetext{
39 Pieris, Tragedi Maluku, 89.

${ }^{40}$ Kwok Pui-Lan, Discovering the Bible in the Non-Biblical World (Eugene, Oregon: Wipf\&Stock Publishers, 2003), 58.

${ }^{41}$ Nindyo Sasongko, "Epistemic Ignorance and the Indonesian Killings of 1965-1966: Righting the Wrongs of the Past and the Role of Faith Community," Political Theology, Vol. 20, No. $3 \quad$ (2019): 280-295, https://doi.org/10.1080/1462317X.2019.1568705.

42 Mery Kolimon, "Peringatan dan Penyembuhan," dalam Perempuan Indonesia dalam Karya dan Pengabdian, eds., Deetje Rotinsulu Tiwa dan Mariska Lauterboom (Jakarta: BPK. Gunung Mulia, 2014), 141-142.
} 
sekolah dan ruang kelas yang mewarisi pendekatan kolonial mendukung polarisasi ini. Maria Harris mengungkapkan bahwa kurikulum itu harus mencakup semua yang dilakukan oleh gereja dan tidak terbatas pada ruang kelas saja. ${ }^{43}$ Upaya dekolonialisasi diharapkan mampu menciptakan berbagai ragam ruang ketiga yang melampaui ruang kelas sebagai tempat atau sarana perjumpaan antara pendeta dan jemaat, perjumpaan dengan sesama (earth beings), dan perjumpaan dengan Tuhan.

Selanjutnya, dualisme antara pikiran (mind) dan tubuh (body) juga menjadi salah satu alasan pentingnya upaya dekolonialisasi di Indonesia. Kesenjangan antara pikiran dan tubuh dalam pelaksanaan pendidikan agama Kristen perlu dijembatani melalui pembelajaran yang melibatkan tubuh dan emosi (embodied learning). Praktik pembebasan dalam pendidikan itu tidak bisa dilakukan tanpa memadukan tubuh dan emosi dalam ruang belajar-mengajar. Dekolonialisasi praksis dibutuhkan, bukan hanya sekadar dekolonialisasi gagasan. ${ }^{44}$ Artinya bahwa proses dekolonialisasi itu harus dilakukan secara menyeluruh, baik di ranah gagasan dan desain kurikulum pendidikan, maupun praksis (termasuk proses produksi pengetahuan).

\section{Imajinasi Dekolonial di Ruang Relasi Belajar-Mengajar}

Dekolonialisasi pendidikan agama Kristen bertujuan untuk pembebasan, keadilan sosial, dan kesetaraan untuk semua. Upaya dekolonialisasi dilakukan bukan hanya untuk mendeteksi, mengidentifikasi berbagai bentuk kolonialisme modern, mengkritisinya, tapi juga berkaitan dengan tindakan atau respons nyata yang bisa dilakukan sebagai bentuk resistensi dan perlawanan terhadap penindasan dan imperialisme tersebut, termasuk dalam pendidikan agama Kristen.

Dalam rangka ini, maka imajinasi dekolonial dibutuhkan baik dalam membaca dan menafsir Alkitab, memahami budaya lokal, dan pengalaman tiap hari yang diingat oleh pikiran tapi juga tubuh (mind and body). Menggunakan istilah imajinasi di sini tidak lalu mengacu pada dualisme tubuh dan pikiran tapi justru sebagai upaya untuk

43 Maria Harris, Fashion Me A People: Curriculum in the Church (Louisville: Westminster/John Knox Press, 1989), 64.

44 bell hooks, Teaching to Transgress: Education as the Practice to Freedom (New York: Routledge, 1994), 193; Marcelo Diversi dan Claudio Moreira, Betweener Talk: Decolonizing Knowledge Production, Pedagogy, and Praxis (New York: Routledge, 2016), 27 29. 
menjembatani dualisme ini. Manusia mengingat dengan otak atau pikiran tapi juga dengan tubuh. Tubuh menyimpan banyak trauma yang perlu untuk diperhatikan dalam pendidikan agama. Pendidikan agama Kristen perlu melibatkan baik pikiran maupun tubuh dalam perjumpaan dengan Tuhan dan sesama. ${ }^{45}$

Imajinasi dekolonial yang ditawarkan di sini merupakan pengembangan dari gagasan Kwok tentang imajinasi poskolonial (postcolonial imagination). ${ }^{46}$ Kwok memahami imajinasi poskolonial dalam kaitan dengan imajinasi historis, imajinasi dialogis, dan imajinasi diasporik. Lebih lanjut dia mengungkapkan bahwa imajinasi poskolonial adalah keinginan, tekad, dan proses melepaskan diri dari semua sindrom kolonial yang hadir dalam beragam bentuk dan wajah di konteks masa kini. ${ }^{47}$ Membawa imajinasi poskolonial ini lebih jauh, saya menawarkan imajinasi dekolonial yang secara khusus memberi tempat bagi narasi budaya lokal (adat) yang begitu kaya di Indonesia sebagai bagian dari sakralitas perjumpaan dengan Tuhan, juga narasi tubuh yang selama ini dipinggirkan dalam praktik pendidikan. Tubuh (body) sama pentingnya dengan pikiran (mind) dalam belajar tentang dan berjumpa dengan Tuhan dan sesama.

Imajinasi dekolonial berkaitan dengan strategi mencegah, menolak, dan merespons diskursus kolonial dalam segala bentuknya. Pendidik diajak untuk menggunakan imajinasi dekolonial ini ketika mendesain kurikulum, ketika berinteraksi dan berelasi dalam ruang belajar-mengajar, baik di dalam kelas (ruang ibadah, tempat PA, sekolah minggu dan sebagainya) maupun di luar kelas (interaksi di ruang ramah tamah di gereja, di luar gereja dan sebagainya). Imajinasi dekolonial ini perlu menjadi bagian dari kompetensi pendidik dan dikembangkan sebagai metode belajar-mengajar sehingga nara didik juga punya kemampuan untuk mengembangkan imajinasi dekolonial ini. Pendeta dan warga jemaat dengan menggunakan imajinasi dekolonial diharapkan mampu mengenali dan menyebutkan (naming) diskursus kolonial yang hadir di tengah kehidupan gereja dan masyarakat. Dengan ini, pendeta dan jemaat adalah partner atau rekan dalam relasi yang setara dalam pendidikan agama Kristen. Ruang relasi yang setara dan membebaskan adalah ruang antara (third-space) yang

45 Tentang pentingnya pengajaran yang memperhatikan trauma dan keterkaitan antara trauma, upaya berteologi dan misi gereja lihat Septemmy Lakawa, "Teaching Trauma and Theology Inspires Lives of Witnessing Discipleship: Theological Education as Missional Foundation," International Review of Mission Vol. 107, No. 2 (2018): 331-346.

46 Pui-Lan Kwok, Postcolonial Imagination and Feminist Theology (Louisville, Kentucky: Westminster John Knox Press, 2005).

47 Ibid., 3. 
mengakomodasi perbedaan, kemajemukan, negosiasi, dan dinamika pembentukan identitas, baik pendeta maupun warga jemaat.

Sarah Travis dalam karyanya Decolonizing Preaching mengklaim beberapa strategi yang dibutuhkan untuk dekolonialisasi khotbah yang menurut saya juga dapat diadopsi sebagai strategi untuk dekolonialisasi pendidikan agama Kristen. ${ }^{48}$ Pertama, mengenali dan menyebutkan atau menamakan diskursus yang menjajah sebagai realita yang terus terjadi dalam konteks kekinian, serta bagaimana merespons kondisi tersebut. Kedua, menghargai perbedaan dan kemajemukan. Ketiga, berhati-hati ketika merepresentasikan sesuatu atau seseorang dalam proses belajar-mengajar. Konsep atau pandangan murid tentang dunia dipengaruhi oleh apa yang dipresentasikan oleh pendidik. Itu sebabnya perlu ada kehati-hatian. Keempat, perlu peka terhadap dinamika kekuasaan (power dynamics) dalam proses belajar-mengajar. Kelima, diperlukan "decentering perspectives." Artinya bahwa pendidikan agama Kristen perlu menyediakan ruang bagi berbagai narasi sebagai sumber belajar-mengajar, bukan hanya Alkitab. Keenam, memfasilitasi negosiasi dan kontradiksi. Ketujuh, penggunanan media yang kreatif. Kedelapan, perlu adanya resistensi dan kritik terhadap diskursus kolonial baik di dalam gereja maupun di luar gereja. Delapan strategi dekolonialisasi ini dapat dikembangkan sesuai dengan kebutuhan masing-masing konteks.

Strategi-strategi di atas sebagai upaya dekolonialisasi pendidikan agama Kristen di konteks poskolonial Indonesia membutuhkan imajinasi dekolonial sehingga ruang relasi belajar mengajar yang membebaskan akan tercipta. Ruang yang dimaksudkan di sini adalah ruang antara yang tidak terbatas dinding gereja atau kelas PA atau sekolah minggu, tapi ruang perjumpaan kreatif antar sesama penghuni bumi (earth beings) yang didalamnya ada relasi yang saling mentransformasi dan membebaskan. Ruang relasi ini peka dan peduli dengan masalah kemiskinan, perang, bencana alam, sakit-penyakit, ketidakadilan, ketidaksetaraan gender, krisis ekonomi, kekerasan dalam rumah tangga, ketidakpastian ekonomi, kerusakan ekosistem dan beragam isu bumi lainnya sebagai narasi penting belajar-mengajar.

Dalam ruang relasi seperti ini pendidik bukan hanya mengajar tapi juga belajar, sama halnya dengan nara didik yang bukan hanya belajar tapi juga saling mengajar. Ruang relasi ini bukan hanya tentang rasa aman, tapi juga rasa takut; bukan hanya tempat mencari kedamaian, tapi juga bertemu dengan konflik dan ketegangan; bukan hanya tempat berbagi cerita tentang keluarga bahagia, tapi juga berbagi cerita kekerasan dalam rumah tangga ataupun kegagalan dalam

\footnotetext{
48 Sarah Travis, Decolonizing Preaching: The Pulpit as Postcolonial Space (Eugene, Oregon: Cascade Books, 2014), 90.
} 
pekerjaan; bukan hanya tempat untuk menemukan kekuatan, tapi juga tempat untuk mengekpresikan kerapuhan; bukan hanya ruang fisik, tapi juga ruang virtual. Inilah tempat dimana pendidikan itu berlangsung.

Dalam perjumpaan relasional seperti inilah Tuhan akan dijumpai sebagai Sang Pembebas. Narasi-narasi lokal yang dimiliki oleh orang Indonesia, tentunya termasuk masyarakat adat, dapat dijadikan sebagai sumber penting dalam pendidikan, bahkan dapat dikembangkan sebagai teologi lokal, seperti misalnya Teologi Ina di Maluku. ${ }^{49}$ Dengan ini maka narasi Alkitab, narasi budaya, dan narasi pengalaman tubuh tiap individu adalah narasi sakral yang menjadi sumber signifikan baik dalam upaya pendidikan agama Kristen maupun berteologi lokal di Indonesia.

\section{Tentang Penulis}

Mariska Lauterboom, Ph.D. (cand.), adalah dosen di Fakultas Teologi Universitas Kristen Satya Wacana, Salatiga. Ia juga adalah Pendeta Gereja Protestan Maluku (GPM) yang ditahbiskan tahun 2008 di Gereja Maranatha, Ambon. Mariska menyelesaikan studi magister di San Francisco Theological Seminary (SFTS), San Anselmo di tahun 2013. Sejak tahun 2016, menempuh program doktoral di bidang Pendidikan Agama pada Graduate Theological Union (GTU), Berkeley, Amerika Serikat. Saat ini, Mariska sedang menulis disertasinya sambil menikmati perannya sebagai seorang ibu dan istri. Bidang minatnya adalah dekolonialisasi pendidikan agama Kristen, ritual dan perempuan, dan pedagogi pembebasan.

\section{Daftar Pustaka}

Antone, Hope S. Religious Education in Context of Plurality and Pluralism. Quezon City: New Day Publishers, 2003.

. "The Shape of Christian Religious Education in Asia."

Religious Education, Vol. 99, No. 1 (2004): 79-85.

Aritonang, Jan S. Mission Schools in Batakland (Indonesia), 1861-1940.

Leiden, New York: E.J. Brill, 1994.

Barongo-Muweke, Norah. Decolonizing Education: Towards Reconstructing

a Theory of Citizenship Education for Postcolonial Africa (Hannover: Springer, 2016).

49 Lihat Yudit Weldemina Tiwery, "Manusia Pertama Itu Namanya Ina: Membaca Narasi Mitos Penciptaan dari Perspektif Perempuan Maluku," Indonesian Journal of Theology, Vol. 5, No.2 (2017): 211-226. 
Battiste, Marie. Decolonizing Education: Nourishing the Learning Spirit. Saskatoon, SK, Canada: Purich Publishing Limited, 2013.

Bhabha, Homi K. The Location of Culture. London and New York: Routledge, 1994.

Bhambra, Gurminder K. "Postcolonial and Decolonial Dialogues," Postcolonial Studies, Vol. 17, No. 2 (2014): 115-121. https://www.tandfonline.com/doi/pdf/10.1080/13688790.2 014.966414.

Boehlke, Robert R. Sejarah Perkembangan Pikiran dan Praktik Pendidikan Agama Kristen: Dari Yohanes Amos Comenius sampai Perkembangan PAK di Indonesia. Jakarta: BPK. Gunung Mulia, 2009.

Christiani, Tabita Kartika. "Biarkan Mereka Bercerita: Pendidikan Kristiani dan Keadilan Gender." Dalam Perempuan Indonesia dalam Karya dan Pengabdian. Eds., Deetje Rotinsulu Tiwa dan Mariska Lauterboom, 13-32. Jakarta: PT. BPK. Gunung Mulia, 2014.

Cooley, Frank. Indonesia: Church and Society. New York: Friendship Press, 1968. . "Altar and Throne in Central Moluccan Societies." Indonesia, No. 2 (October 1966): 135-156.

Diversi, Marcelo, and Claudio Moreira. Betweener Talk: Decolonizing Knowledge Production, Pedagogy, and Praxis. New York: Routledge, 2016.

Dube, Musa W. Postcolonial Feminist Interpretation of the Bible. St. Louis, Missouri: Chalice Press, 2000.

van den End, Th. Ragi Carita: Sejarah Gereja di Indonesia 1, 1500-1860. Jakarta: PT. BPK. Gunung Mulia, 1988.

van den End, Th. dan Jan S. Aritonang, "1800-2005: A National Overview." In A History of Christianity in Indonesia. Eds., Jan Sihar Aritonang and Karel Steenbrink. Leiden and Boston: Brill, 2008.

Farhadian, Charles E. Christianity, Islam, and Nationalism in Indonesia. New York and London: Routledge, 2005.

Fitriyah, Lailatul. "Religious Peacebuilding in Post-War Maluku: Tiwery's Theology of the Mother (Teologi-Ina) and Nunusaku-based Cosmology." Interreligious Relations, No. 10 (2019): 1-12.

Freire, Paulo. Pedagogy of the Oppressed. New York: Continuum, 2011. Harris, Maria. Fashion Me A People: Curriculum in the Church. LouisvilleKentucky: Westminster/John Knox Press, 1989.

Hattu, Justitia Vox Dei. "Protestantisme dan Pendidikan Kristiani." Dalam Menuju Gereja Orang Basudara: Refleksi 500 tahun Protestantisme dari Maluku. Eds., Rudolf Rahabeat dan Johan 
Saimima. Salatiga: Satya Wacana University Press dan Sinode GPM, 2017. . Mewarga Dengan Hati: Pembelajaran Transfromatif sebagai Respon Pedagogis Kristiani terbadap Tantangan Pendidikan Kewarganegaraan dalam Konteks Indonesia Masa Kini. Jakarta: BPK Gunung Mulia dan ST'T Jakarta, 2018.

hooks, bell. Teaching to Transgress: Education as the Practice to Freedom. New York: Routledge, 1994.

Kolimon, Mery. "Peringatan dan Penyembuhan." In Perempuan Indonesia dalam Karya dan Pengabdian. Eds., Deetje Rotinsulu Tiwa and Mariska Lauterboom, 127-152. Jakarta: PT. BPK. Gunung Mulia, 2014.

Kwok Pui-Lan, Discovering the Bible in the Non-Biblical World. Eugene, Oregon: Wipf\&Stock Publishers, 2003.

Lakawa, Septemmy. "Teaching Trauma and Theology Inspires Lives of Witnessing Discipleship: Theological Education as Missional Foundation." International Review of Mission, Vol. 107, No. 2 (2018): 331-346.

Lavia, Jennifer and Sechaba Mahlomahalo, eds. Culture, Education and Community: Expressions of the Postcolonial Imagination. New York: Palgrave Macmillan, 2012.

Lee, Boyung. Transforming Congregations through Community: Faith Formation from the Seminary to the Church. Louisville, Kentucky: Westminster John Knox Press, 2013.

. "Toward Liberating Interdependence: Exploring an Intercultural Pedagogy." Religious Education, Vol. 105, No. 3 (2010): 283-298.

Mangililo, Ira D. "When Rahab and Indonesian Christian Women Meet in the Third Space." Journal of Feminist Studies in Religion, Vol. 31, No. 1 (2015): 45-64.

Palmer, Parker. To Know As We Are Known: Education as a Spiritual Journey. New York: Harper Collins, 1993.

Pieris, John. Tragedi Maluku: Sebuah Krisis Peradaban. Jakarta: Yayasan Obor Indonesia, 2004.

Sasongko, Nindyo. "Epistemic Ignorance and the Indonesian Killings of 1965-1966: Righting the Wrongs of the Past and the Role of Faith Community." Political Theology, Vol. 20, No. 3 (2019): 1-16. https://doi.org/10.1080/1462317X.2019.1568705.

Segovia, Fernando F. Decolonizing Biblical Studies: A View from the Margins. Maryknoll: Orbis Books, 2000.

Souisa, Nancy. "Makan Patita: Nilai dan Maknanya dalam Membangun Pendidikan Kristiani yang Kontekstual." Disertasi. Universitas Kristen Satya Wacana, 2017. 
Smith, Linda Tuhiwai. Decolonizing Methodologies: Research and Indigenous Peoples. Indigenous People. London, New York, and Dunedin: Zed Books Ltd and University of Otago Press, 2004.

Tiwery, Yudit Weldemina. "Manusia Pertama Itu Namanya Ina: Membaca Narasi Mitos Penciptaan dari Perspektif Perempuan Maluku." Indonesian Journal of Theology, Vol. 5, No.2 (2017): 211-226.

Tolbert, Mary Ann. "A New Teaching with Authority: A Reevaluation of the Authority of the Bible." In Teaching the Bible: The Discourse and Politics of Biblical Pedagogy. Eds., Fernando F. Segovia and Mary Ann Tolbert, 168-189. Maryknoll: Orbis Books, 1998.

Tye, Karen B. Basics of Christian Education. St. Louis, Missouri: Chalice Press, 2000. 